\title{
Development and Assessment of Conformance of Cowpea Flour for Cake Production
}

\author{
Agboka Judith Akosua, Kpodo Fidelis Mawunyo Kwasi, Dzah Courage Sedem, \\ Mensah Christopher \\ Department of Hospitality and Tourism Management, Faculty of Applied Science and Technology, Ho Polytechnic, Ho, Ghana
}

Email address:

judithagboka@yahoo.com (A. J. Akosua), fideliskpodo@yahoo.com (K. F. M. Kwasi)

\section{To cite this article:}

Agbokah Judith Akosua, Kpodo Fidelis Mawunyo Kwasi, Dzah Courage Sedem, Mensah Christopher. Development and Assessment of Conformance of Cowpea Flour for Cake Production. International Journal of Nutrition and Food Science. Vol. 4, No. 3, 2014, pp. $320-325$. doi: $10.11648 /$ j.jinfs. 20150403.19

\begin{abstract}
Cowpea is a nutritious component in human diet as well as livestock feed. It is of major importance to the livelihoods of millions of people in developing countries because it is an important source of proteins, minerals and vitamins. The leaves, pods and seeds of cowpea are consumed. This study explored the feasibility of preparing a Supreme Quality Cowpea Flour (SQCF) as a substitute for wheat flour for the preparation of cakes. Development of the composite cowpeawheat flour followed a $3 \times 2$ factorial design with cowpea-wheat proportions (100\%:0\%, 75\%:25\% and 50\%:50\%) and heat treatments $\left(150\right.$ and $\left.200{ }^{\circ} \mathrm{C}\right)$ as factors. The composite flour produced was then used to produce cake and evaluated sensorially based on ranking for preference. Hundred percent $(100 \%)$ wheat flour cake was used as control. The composite flour with proportion 50\%:50\% cowpea: wheat baked at $200{ }^{\circ} \mathrm{C}$ produced the most preferred cake which was significantly higher $(\mathrm{P}<$ $0.05)$ in terms of taste $(7.22 \pm 2.01)$ and overall acceptability $(7.03 \pm 1.82)$ when compared with the taste $(6.67 \pm 1.84)$ and overall acceptability $(6.80 \pm 1.81)$ of the control. The application of this by industry will encourage the use of cowpea, a readily available legume for the production of cake.
\end{abstract}

Keywords: Cakes, Composite Flour, Cowpea, Supreme Quality Cowpea Flour (SQCF)

\section{Introduction}

Cakes are unleavened pastries made mainly from wheat flour, shortening, sugar, egg, milk and little or no baking powder [1]. Wheat flour is well suited for making pastry products because of its unique protein called gluten. The gluten protein forms an elastic network which is essential for dough development [2]. Although wheat is a good source of calories and other nutrients, its protein content is of lower nutritional quality when compared to soy bean, peanut and cowpea [3]. Coupled to its deficiency in some essential amino acid, virtually all of Ghana's wheat consumption is through imports from primarily the US, Canada, Argentina, and the EU. Currently 90 percent of all wheat is imported from the U.S. with the remaining 10 percent being imported from the other sources previously mentioned [4]. In 1998, Ghana imported 278,334 metric tons of wheat for an overall value of 35.6 million dollars, up 39 percent when compared to 1997. This made Ghana the fourth largest wheat importer in the Sub-Saharan Region. Ghana is also the second largest importer of U.S. wheat in the Sub-Saharan region [4,5].

In order to reduce the nation's expense on wheat importation other flour products from indigenous crops such as cowpea should be developed and their utilization for baking pastries encouraged. Cowpea is the second most important legume in Ghana after groundnut. Ghana has been self-sufficient in cowpea production over the last decade with production outstripping consumption [6]. Cowpea contributes a significant amount of protein and water-soluble vitamins to the African diet. The cowpea seed is a nutritious component in the human diet as well as livestock feed. Cowpea is of major importance to the livelihoods of millions of people in developing countries of the tropics particularly in Asia and Africa. It is consumed in many forms: young leaves, green pods and green seeds are used as vegetable and the dry seeds are used in various food preparations. Cowpea is a major source of protein, minerals and vitamins in daily diets and thus it positively impacts on the health of consumers.

Besides the nutritional benefits that can be derived from cowpeas, it is one of the drought-resistant food crops grown 
by farmers in Ghana, especially in the rural settings. These rural communities are largely deprived of essential social amenities with many poor households benefiting immensely in economic terms if cowpeas are demanded in higher quantities. This will aid in the alleviation of poverty in Ghana and other developing countries. There is an increasing world demand for less expensive proteins with good nutritional and functional properties, particularly in developing and underdeveloped countries where the supply of food of animal origin is limited due to non-availability and high cost [7]. Enrichment of cereal-based foods with legume protein has received considerable attention because cereal proteins are generally low in lysine and total protein content although high in sulphur amino acids [8]. Combination of these cereal products with cheaper and more available plant proteins sources like cowpea can improve the nutritional quality of cereal based foods. Cowpea is used in diverse ways around the globe for the preparation of Salads, Casseroles, Fritters, Bean cakes (koose, agawu), Curry dishes and Southern dishes with ham and rice. The main objective of this study is to develop and assess composite cowpea-wheat flour for cake preparation. In addition, to evaluate the cakes produced from cowpea-wheat flour sensorially based on ranking for preference.

\section{Material and Methods}

\subsection{Materials}

Wheat flour (Triticum aestivum) and cowpea beans (Vigna unguiculata) were used to develop the composite wheatcowpea flour. The raw materials were purchased from a source supplier at a local market in Ho. The cowpea beans were then sorted to remove foreign materials and stored in a cool, dry place prior to its use for production of the flours. Other ingredients purchased included margarine, eggs, nutmeg, vanilla essence and sugar.

\subsection{Preparation of Supreme Quality Bean Flour (SQBF)}

The cowpea beans were sorted to remove unwholesome ones and foreign materials. The sorted beans were parboiled ( 5 minutes) for easy removal of skin and the black eyes. The parboiled beans were dehulled to remove the outer covering including the black eye. The dehulled beans were dried in convection oven at a temperature of $150^{\circ} \mathrm{C}$ for 3 hours. The oven dried beans were milled into refined bean flour referred to as supreme quality bean flour and stored in an air tight container (Figure 1).

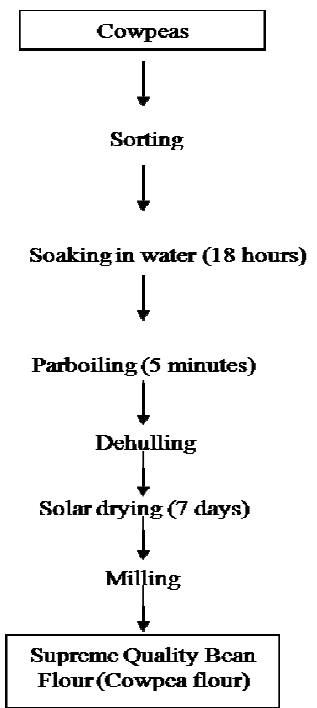

Figure 1. Flowchart of the procedure for Supreme Quality Bean Flour (SQBF) production.

\subsection{Experimental Design}

A $3 \times 2$ full factorial design was employed, and the factors were; a) percentage of cowpea flour (SQBF)-wheat flour (50:50, 75:25 and 100 cowpea flour) and b) the baking temperatures $\left(150\right.$ and $\left.200{ }^{\circ} \mathrm{C}\right)$. Cake of $100 \%$ wheat flour baked at $200{ }^{\circ} \mathrm{C}$ was used as control.

\subsection{Preparation of Cowpea-Wheat Cake}

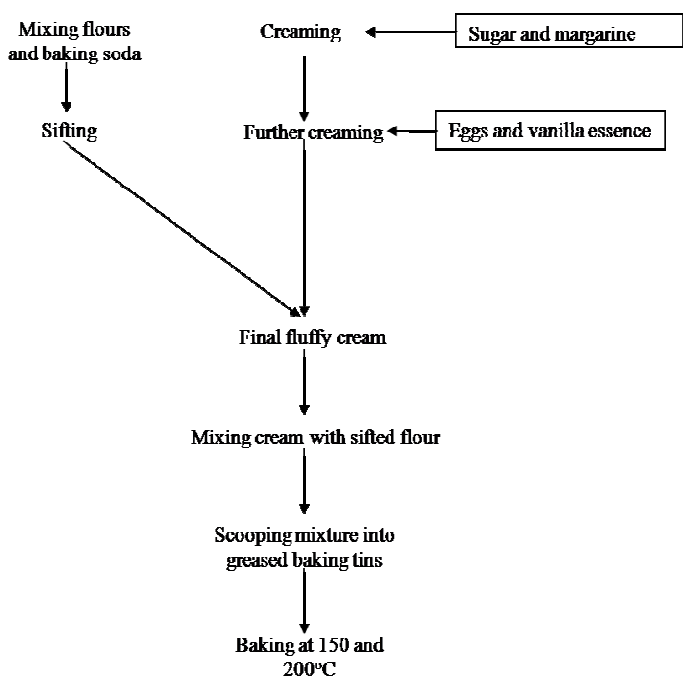

Figure 2. Flowchart of cake baking process. 
Sugar and margarine (Table 1) were creamed until fluffy (Figure 2). The eggs and vanilla essence (Table 1) were then added and creamed further for 6-10 minutes. The refined cowpea flour (100\%) / cowpea: wheat flour composite/ wheat flour $(100 \%)$ were combined with baking powder, sifted and poured into the sugar and margarine mixture. The flour was folded into the mixture and scooped into greased baking tins and baked in oven at temperatures of 150 and $200{ }^{\circ} \mathrm{C}$ (Figure 2 ). This procedure was followed to produce cakes containing cowpea: wheat composite flour in the following percentages, 50:50, 75:25 and 100\% cowpea flour. Another cake was baked with $100 \%$ wheat flour which served as control for sensory evaluation.

Table 1. Recipe for QSBF Cake (100\%).

\begin{tabular}{ll}
\hline Ingredient & Quantity \\
\hline Margarine & $250 \mathrm{~g}$ \\
Eggs & 5 medium pieces \\
Sugar & $250 \mathrm{~g}$ \\
Vanilla essence & $28 \mathrm{ml}$ \\
Powdered nutmeg & 2 teaspoons \\
Baking powder & 2 teaspoons \\
Lemon juice & 2 tablespoons \\
Browning & 3 tablespoons \\
\hline
\end{tabular}

\subsection{Sensory Evaluation}

Table 2. Cake sample description.

\begin{tabular}{lll}
\hline Sample & Formulation $(\%)$ & Baking Temperature $\left({ }^{\mathbf{0}} \mathbf{C}\right)$ \\
\hline A & 50 cowpea:50 wheat & 150 \\
B & 75 cowpea:25 wheat & 150 \\
C & 100 cowpea & 150 \\
D & 50 cowpea:50 wheat & 200 \\
E & 75 cowpea:25 wheat & 200 \\
F & 100 cowpea & 200 \\
G (control) & 100 wheat & 200 \\
\hline
\end{tabular}

The sensory evaluation was done on 7 different cake samples (A,B,C,D,E,F,G) as shown in Table 2. A total of thirty fife (35) untrained panellists were randomly recruited from among students in Ho Polytechnic, Ho. The criteria for recruitment were that they were familiar with the quality parameters of cake, had no health conditions associated with eating cake and willing to participate in the test. Panellists were asked to evaluate the 7 randomly coded samples on a 9
- point hedonic scale (1 extremely, 5 - neither like nor dislike and 9 extremely) in an experiment for sensory evaluation on parameters (colour, taste, mouth feel, flavour and overall acceptability). The samples were rated using a nine points hedonic scale with $1=$ dislike like extremely, $5=$ neither like nor dislike and $9=$ like extremely. The test was carried out in a well illuminated room free of environmental factors that could interfere with the normal perception of panellists.

\subsection{Data Analysis}

Data was analysed using analyses of variance (ANOVA). Individual consumer preference scores from panellists were averaged and data analyzed using SPSS 17.0.1. Statistical significance was set at a level of $95 \%$ confidence interval. The difference between mean values was determined by least significant difference (LSD) test. Significance was accepted at $\mathrm{P}<0.05$.

\section{Results and Discussion}

\subsection{Sensory Characteristics of Composite Cowpea-Wheat Cake}

Sensory evaluation is a critical stage in product development and product optimization studies, because products targeted at consumers must first appeal sensorially to them [9]. Sensory attributes evaluated included colour, taste, flavour, mouth feel and overall acceptability. A summary of the mean scores for the sensory attributes is shown in Table 3. For each attribute the scores were made on a scale of 1 to 9 on a hedonic scale where 1 was the least liked and 9 the most liked. The means for the attributes taste and overall acceptability were significantly different $(\mathrm{P}<$ 0.05 ) for all formulations. Formulations however did not show significant differences $(\mathrm{P}>0.05)$ in the mean scores for colour, mouth feel and flavour (Table 3). On the whole all cake formulations including the control $(100 \%$ wheat baked at $200^{\circ} \mathrm{C}$ ) ranged from 5.03 (neither like nor dislike) to 7.22 (like moderately). The composite cake sample with equal amounts of wheat and cowpea baked at $200^{\circ} \mathrm{C}$ (D) rated better for taste, flavour and overall acceptability relative to other formulations including the control (whole wheat baked at $200^{\circ} \mathrm{C}$ ) (Table 3). However consumer preference in terms of colour and mouth feel was higher in the control $(\mathrm{G})$.

Table 3. Sensory evaluation of cake samples.

\begin{tabular}{llllll}
\hline Treatment & Colour & Taste & Mouth feel & Flavour & Overall acceptability \\
\hline A & $5.45( \pm 2.10)^{\mathrm{a}}$ & $6.08( \pm 2.18)^{\mathrm{ab}}$ & $5.91( \pm 2.10)^{\mathrm{a}}$ & $6.11( \pm 1.87)^{\mathrm{a}}$ & $5.88( \pm 1.96)^{\mathrm{a}}$ \\
B & $6.40( \pm 1.92)^{\mathrm{a}}$ & $6.37( \pm 1.81)^{\mathrm{abc}}$ & $5.74( \pm 1.91)^{\mathrm{a}}$ & $6.03( \pm 2.02)^{\mathrm{a}}$ & $6.83( \pm 1.52)^{\mathrm{bc}}$ \\
C & $5.66( \pm 2.24)^{\mathrm{a}}$ & $5.65( \pm 2.41)^{\mathrm{a}}$ & $5.74( \pm 2.26)^{\mathrm{a}}$ & $5.83( \pm 2.09)^{\mathrm{a}}$ & $6.00( \pm 2.10)^{\mathrm{ab}}$ \\
D & $6.08( \pm 1.91)^{\mathrm{a}}$ & $7.22( \pm 2.01)^{\mathrm{c}}$ & $5.94( \pm 2.32)^{\mathrm{a}}$ & $6.66( \pm 2.14)^{\mathrm{a}}$ & $7.03( \pm 1.82)^{\mathrm{c}}$ \\
E & $5.77( \pm 2.23)^{\mathrm{a}}$ & $5.83( \pm 2.35)^{\mathrm{ab}}$ & $5.34( \pm 2.53)^{\mathrm{a}}$ & $5.97( \pm 2.26)^{\mathrm{a}}$ & $6.03( \pm 2.20)^{\mathrm{ab}}$ \\
F & $6.54( \pm 2.22)^{\mathrm{a}}$ & $5.94( \pm 2.48)^{\mathrm{ab}}$ & $5.08( \pm 2.13)^{\mathrm{a}}$ & $5.66( \pm 1.96)^{\mathrm{a}}$ & $6.08( \pm 2.02)^{\mathrm{ab}}$ \\
G & $6.68( \pm 1.95)^{\mathrm{a}}$ & $6.67( \pm 1.84)^{\mathrm{bc}}$ & $6.74( \pm 1.78)^{\mathrm{a}}$ & $6.22( \pm 1.91)^{\mathrm{a}}$ & $6.80( \pm 1.81)^{\mathrm{bc}}$ \\
\hline
\end{tabular}

Means sharing the same letters in a column are non-significant $(\mathrm{P}>0.05)$ 


\subsection{Effect of Formulation Components on Taste}

The mean scores for taste of formulations ranged from $5.94 \sim 6.00$ (like slightly) to 7.22 (like moderately). The differences in the taste of formulations were statistically significant $(\mathrm{P}<0.05)$. Since sugar was held constant in all samples, differences that may have occurred among formulations were due to individual component difference of the formulations. The cake formulation that tasted best was D (50\% wheat and 50\% cowpea) which contained equal amounts of cowpea and wheat baked at $200^{\circ} \mathrm{C}$. This result confirms that of Atef et al. (2011) having the best cake with 50\%:50\% cowpea-wheat composite flour. It had a mean score of 7.22 statistically higher than the control value of $6.67(\mathrm{P}<0.05)$. Taste was however least preferred (5.65) in the whole cowpea cake baked at $150^{\circ} \mathrm{C}$ which is substantiated by Atef et al. (2011) who reported that increasing amounts of cowpea negatively influenced the taste of cakes. Considering this effect on taste, McWatters (1995) also used cowpea flour to substitute wheat flour in preparing muffins, noodles and tortillas but kept the percentages of cowpea low ( $8 \%$ to $43 \%$ ). Whole cowpea cake formulation baked at $200^{\circ} \mathrm{C}$ had a mean test score of 5.94, a value significantly higher than the same product baked at $150^{\circ} \mathrm{C}$. Taste mean scores for formulations $\mathrm{A}, \mathrm{E}$ and $\mathrm{F}$ were not significantly different $(\mathrm{P}<0.05)$.

\subsection{Effect of Formulation Components on Colour}

The appearance of food products either colour alone or in conjunction with other quality attributes influences consumer decision at the point of sale. Colour is the most important appearance attribute of food products. The colour of the cake formulations had mean scores ranging from 5.45 (neither like nor dislike) to 6.68 (like moderately). Although the mean score attribute for colour was higher for the control sample, it was not significantly different from the other formulations $(\mathrm{P}$ $<0.05)$. Ellin et al. (2004) indicated that in cowpea-wheat formulations, products get progressively darker when the proportion of cowpea in the composite flour increases. The darkening of these products have been attributed to Maillard reactions during baking of cowpea products. Maillard reactions are chemical reactions that occur between reducing sugars and the amino group of proteins or amino acids such as lysine [13]. The high lysine content of cowpea might have contributed to the low sensory scores for colour in the cowpea rich products when compared with the control.

\subsection{Effect of Formulation Components on Flavour}

Flavour is the most important sensory attribute that affects acceptability of foods [14]. Mean scores for flavour were not statistically significant $(\mathrm{P}>0.05)$. Cake developed with whole cowpea flour baked at either 150 or $200^{\circ} \mathrm{C}$ recorded the least scores for flavor whereas cake prepared with composite wheat and cowpea flour of equal proportions baked at 150 and $200^{\circ} \mathrm{C}$ recorded the highest scores. Also flavour generally improved as proportion of cowpea decreased in samples. This is in line with other findings by Tortoe et al. (2014) and Olapade et al. (2012) that high amounts of cowpea negatively affect consumer acceptability in products due to its beany flavour.

\subsection{Effect of Formulation Components on Mouth Feel}

All cake samples scored between 5.08 and 5.94 (neither like nor dislike) for mouth feel with the exception of the control which was liked moderately. Thus mouth feel generally had the least score relative to the other sensory attributes (Table 3). Other studies showed that high cowpea inclusion levels increase product coarseness which negatively influence mouth feel especially in products which are generally perceived by consumers to have fine mouth feel like cakes $[15,16]$.

\subsection{Effect of Formulation Components on Overall Acceptability}

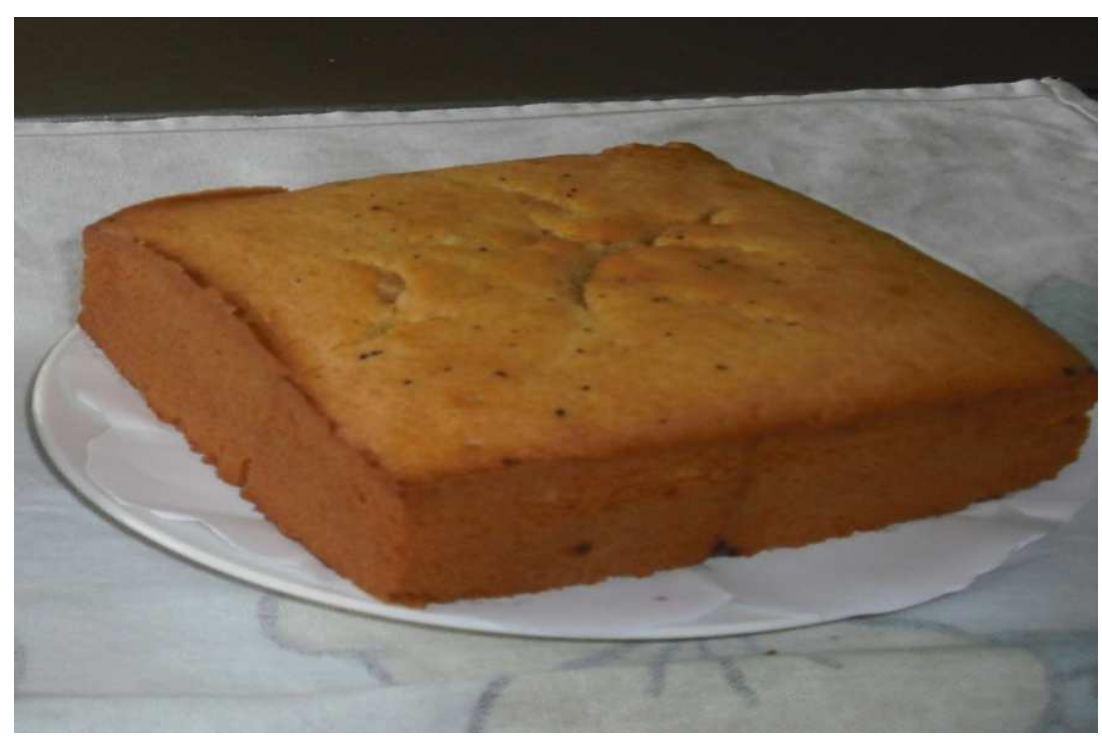

Figure 3. Supreme Quality Bean Flour-SQBF Cake (D: $50 \%$ cowpea: $50 \%$ wheat at $200^{\circ} \mathrm{C}$ ). 
Overall acceptability scores for samples ranged from 5.88 $\sim 6.00$ (like slightly) to 7.03 (like moderately) (Table 3). Significant difference $(\mathrm{P}<0.05)$ was observed for cake formulation D (Figure 3) which consisted of equal amounts of wheat and cowpea baked at $200^{\circ} \mathrm{C}$ with mean preference score (7.03) and the control G- $100 \%$ wheat baked at $200^{\circ} \mathrm{C}$ (6.8) and formulation B (6.83). Acceptability score for formulation $\mathrm{B}(6.83)$ which consisted of $75 \%$ cowpea and $25 \%$ wheat baked at $150^{\circ} \mathrm{C}$ was not significantly different $(\mathrm{P}>$ $0.05)$ from control G-100\% wheat baked at $200^{\circ} \mathrm{C}$ (6.8) (Figure 4).
Beany flavor associated with cowpea has been known to negatively affect consumer acceptability in products containing high amounts of cowpea $[15,16]$. However, cake sample D outperformed the control which contained no cowpea. Hot water treatment and dehulling have been found to reduce beany flavor in legumes such as cowpea used in foods $[17,18]$. The equal amounts of cowpea and wheat components $(50: 50 \%)$, coupled with dehulling, parboiling and the use of vanilla essence explains the masking of beany flavor in sample $\mathrm{D}$, hence its better performance compared to control $(\mathrm{G})$.

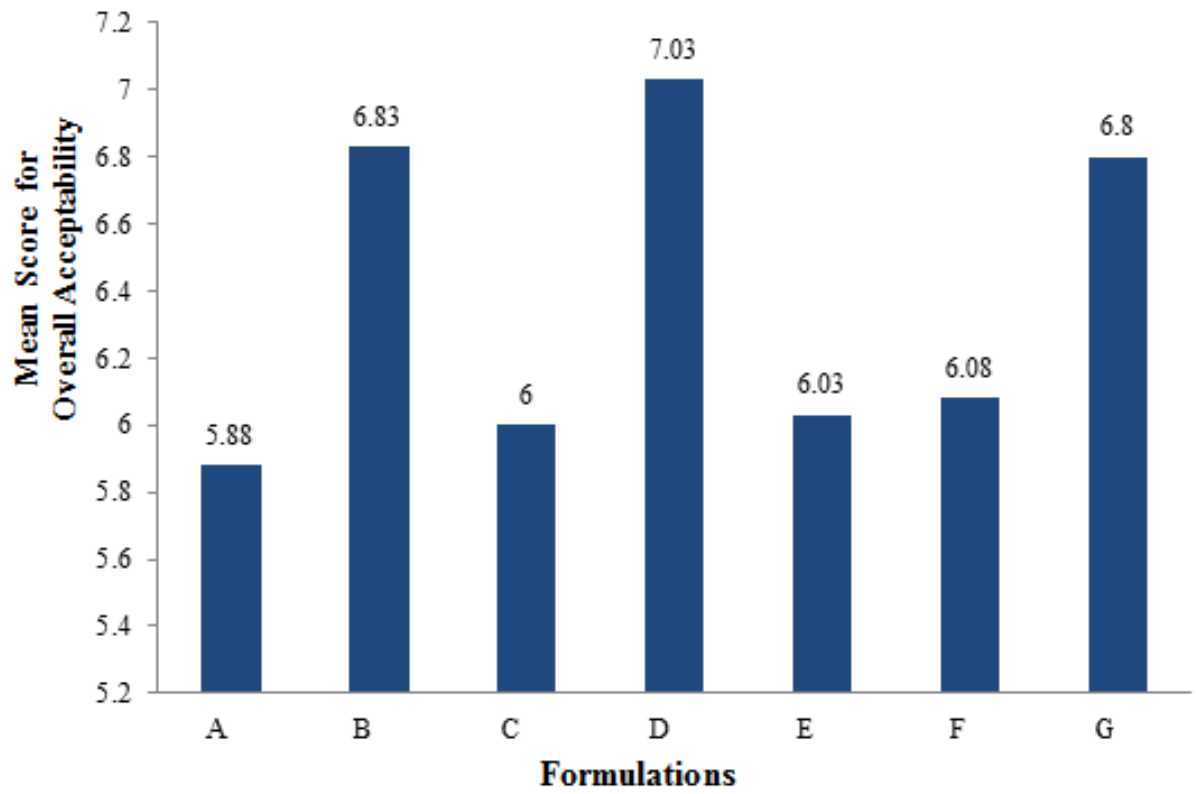

Figure 4. Mean scores for overall acceptability for all samples. A (50cowpea:50wheat $/ 150^{\circ} \mathrm{C} ; \mathrm{B}\left(75 \mathrm{cowpea}: 25\right.$ wheat $\left./ 150^{\circ} \mathrm{C}\right) ; \mathrm{C}\left(100 \mathrm{cowpea} / 150^{\circ} \mathrm{C}\right) ; \mathrm{D}$ (50cowpea:50wheat $\left./ 200^{\circ} \mathrm{C}\right) ; \mathrm{E}\left(75\right.$ cowpea: 25 wheat $\left./ 200^{\circ} \mathrm{C}\right) ; \mathrm{F}\left(100\right.$ cowpea $\left./ 200^{\circ} \mathrm{C}\right) ; \mathrm{G}\left(100\right.$ wheat $\left./ 200^{\circ} \mathrm{C}\right)$.

\section{Conclusion}

The composite flour consisting of 50\% cowpea and $50 \%$ wheat flour baked at $200^{\circ} \mathrm{C}$ yielded the best cake product which was significantly higher in terms of taste and overall acceptability when compared with the control $(100 \%$ wheat cake). Hence composite flour consisting of $50 \%$ wheat and $50 \%$ cowpea flours can be used as a suitable replacement for the $100 \%$ wheat flour traditionally used for cake production. Since the overall acceptability rating for the composite flour (75\% cowpea: $25 \%$ wheat) baked at $150^{\circ} \mathrm{C}$ was not significantly different from control $(100 \%$ wheat baked at $200^{\circ} \mathrm{C}$ ), this composite flour can also be used instead of the control to encourage the utilization of indigenous crops such as cowpea in food products and subsequently help reduce the cost of cake products.

\section{References}

[1] Ugwuona FU, Ogara JF, Awogbenja MD 2012. Chemical and sensory quality of cakes formulated with wheat, soybean and cassava flours. Indian J. L. Sci. 1,1 -6.
[2] Onuegbu NC, Ihediohanma NC, Odunze OF, Ojukwu M 2013. Efficiency of wheat: maize composite flour as affected by baking method in bread and cake production. Sky. J Food Sci. 2,5-18.

[3] Ndife J, Abdulraheem LO, Zakari UM, 2011. Evaluation of the nutritional and sensory quality of functional breads prepared from whole wheat and soybean flour blends. Afr. J. Food Sci. 5(8), $466-472$.

[4] Kessel F 1999. Ghana Grain and Feed Annual Report. USDA Foreign Agricultural Service, GRAIN Report N19006, Washington DC.

[5] Food and Agricultural Organization of the United Nations Statistics (FAO Statistics)(2000). Rome, Italy.

[6] MoFA. 2009. Statistics, Research and Information Directorate (SRID). Ministry of Food and Agriculture.

[7] Mune MAM, Minka SR, Mbome IL 2013. Chemical composition and nutritional evaluation of a cowpea protein concentrate. Global Ad Res J Food Sci and Tech. 3, 35 - 43.

[8] Akubor PI 2004. Protein Contents, physical and sensory properties of Nigerian snack foods (cake, chin-chin and puffpuff) prepared from cowpea-wheat flour blends. Int. J. Food Sci. Technol. 39, $419-424$. 
[9] Atef AM, Mostafa TR, Samia AA 2011. Utilization of Faba Bean and Cowpea Flours in Gluten Free Cake Production. Aust. J. Basic\& Appl. Sci, 5(12), 2665-2672.

[10] McWatters KH, Resurreccion AVA, Beuchat LR, Phillips RD 1995.Use of peanut and cowpea in wheat-based products containing composite flours. Plant Foods Hum. Nutr.47, 71-87.

[11] Ellin H, Ilbanoglu S, Ainsworth P 2004. Effect of fermented/germinated cowpea flour addition on the rheological and baking properties of wheat flour. J. Food Eng.63, 177 - 184

[12] Vaclavik VA, Christian EW 2008. Essentials of Food Science. 3rd edition, Springer Science and Businness Media, NY, USA.

[13] Prinyawiwatkul W, Beuchat LR, McWatters KH, Philips RD 1997. Optimizing acceptability of chicken nuggets containing fermented cowpea and peanut flours. J. Food Sci.62, 889 - 901

[14] Kpodo MK., Afoakwa OE, Amoa BB, Saalia KF 2014. Nutritional and sensory characterization of full fat and partially defatted peanut soy milk yoghurt.. Int. J Nutr Food Sci. 3(3), 187-193.

[15] Tortoe C, Akonor PT, Nketia S, Owusu M, Glover-Amengor M, Hagan L, Padi A 2014. Assessing the sensory characteristics and consumer preferences of yam-cowpeasoybean porridge in the Accra Metropolitan Area. Int. J Nutr Food Sci.3(2),127-132.

[16] Olapade A A, Oluwole OB, Aworh OC 2012. Physicochemical properties and consumer acceptance of instant cowpea (Vigna unguiculata) powder for complementary food. Afr. J. Food Sci \& Tech. 3,102-106.

[17] Taiwo KA 1998. The potential of cowpea as human food in Nigeria. Technovation. 18(6/7), 469-481.

[18] Olapade AA, OluwoleOB, Aworh OC 2012. Physico-chemical properties and consumer acceptance of instant cowpea (Vigna unguiculata) powder for complementary food. Afr. J. Food Sci \& Tech. 3,102-106. 